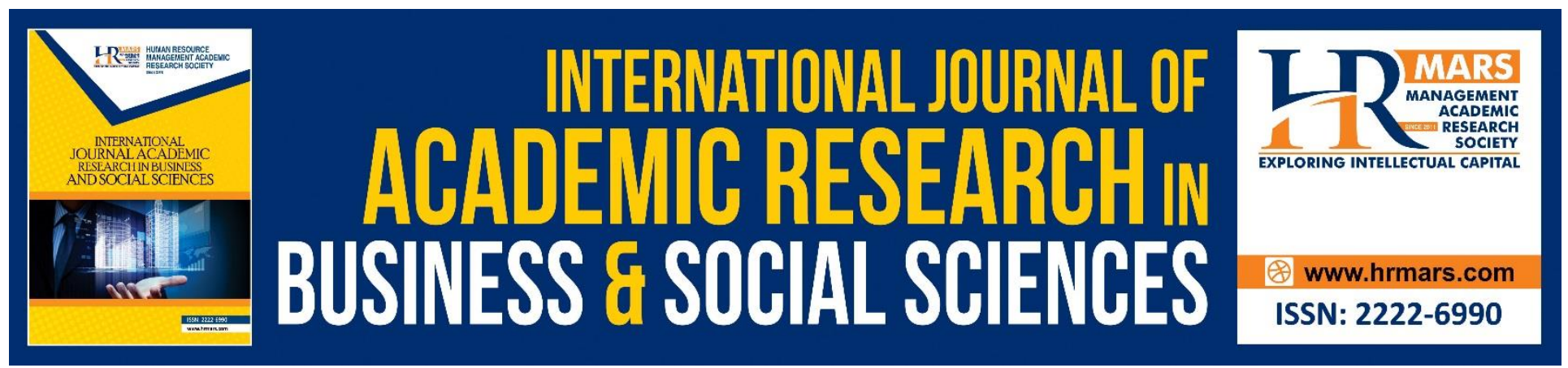

\title{
Wedding Expenses by the Malay-Muslim Community: An Investigation into the Sources of Expenditure
}

Syh Noorul Madihah Syed Husin, Raihanah Azahari, Asmak Ab. Rahman

To Link this Article: http://dx.doi.org/10.6007/IJARBSS/v8-i10/4750

DOI: $10.6007 /$ IJARBSS/v8-i10/4750

Received: 23 Sept 2018, Revised: 17 Oct 2018, Accepted: 27 Oct 2018

Published Online: 31 October 2018

In-Text Citation: (Husin, Azahari, \& Rahman, 2018)

To Cite this Article: Husin, S. N. M. S., Azahari, R., \& Rahman, A. A. (2018). Wedding Expenses by the MalayMuslim Community: An Investigation into the Sources of Expenditure. International Journal of Academic Research in Business and Social Sciences, 8(10), 481-499.

Copyright: (c) 2018 The Author(s)

Published by Human Resource Management Academic Research Society (www.hrmars.com)

This article is published under the Creative Commons Attribution (CC BY 4.0) license. Anyone may reproduce, distribute, translate and create derivative works of this article (for both commercial and non-commercial purposes), subject to full attribution to the original publication and authors. The full terms of this license may be seen

at: http://creativecommons.org/licences/by/4.0/legalcode

Vol. 8, No. 10, 2018, Pg. 481 - 499

http://hrmars.com/index.php/pages/detail/IJARBSS

JOURNAL HOMEPAGE

Full Terms \& Conditions of access and use can be found at http://hrmars.com/index.php/pages/detail/publication-ethics 


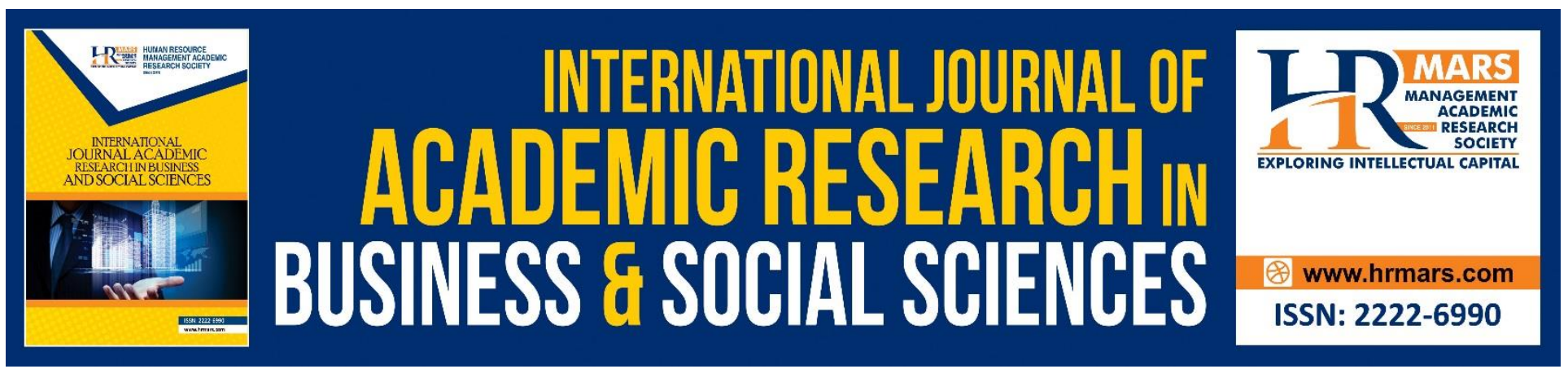

\title{
Wedding Expenses by the Malay-Muslim Community: An Investigation into the Sources of Expenditure
}

\author{
Syh Noorul Madihah Syed Husin \\ Faculty of Islamic Contemporary Studies University of Sultan Zainal Abidin, Malaysia. \\ Raihanah Azahari, Asmak Ab. Rahman \\ Universiti Malaya, Kuala Lumpur
}

\begin{abstract}
The contemporary Malay community is increasingly facing a wedding expenses issue following the existence of various pre-wedding preparations, including the demand of customary rites and current reception trends. In order to face this issue, preparing a source of expenditure is one of the elements that should be considered much earlier. Thus, by not prioritising matters related to the source of expenditure, it could have an effect on managing expenditure. Hence, this study explored the sources of wedding expenditure among the Malay-Muslim community. This study was qualitative in nature and involved 30 couples selected through the purposive method, who then participated in a semi-structured personal interview session. The recording of the interview was transcribed and analysed according to the thematic method as stipulated in this study. By using the ATLAS.ti version 7.5.6. software, the data were investigated and later coded and categorised based on the characteristics of the data in order to adduce the themes related to the phenomenon being studied. The findings showed that there were four sources of expenditure used by the respondents in the study, namely savings, contributions, loans and special funds. Out of the four, three are endorsed by Islam, except loans.
\end{abstract}

Keywords: Wedding Expenses, Wedding, Source of Wedding Expenses, Loans, Interview

\section{INTRODUCTION}

Marriage expenses refer to what needs to be spent for a wedding. Wedding preparations among the Malay community needs a special provision for expenses. The present scenario shows that the community has to spend a huge amount to manage a wedding, especially communities that live in urban areas (Penang Consumer Association, 1987). In order to celebrate Malay wedding customs, the individual who intends to get married needs to start spending before the actual wedding ceremony itself, beginning with the ring for the merisik ceremony (Salleh, 2010), proposal (Kasimin, 2002) and engagement (Strange, 1981) as well as gifts for the engagement (Kasimin, 1989). Hence, for the sake of bonding the marriage, preparing the dowry money (hantaran), which is an obligatory payment 
according to Malay culture (Rahman, 2007), is seen to increasingly burden the bridegroom's side (Maarof \& Majid, 2015). According to Azahari, Saripudin and Wahab (2009), the present dowry money rate is far higher compared to the obligatory dowry (mas kahwin) rate, especially for those living in states that have stipulated the minimum rate. Besides various customary rites, the present trend in celebrating wedding functions, such as in posh hotels or halls as the location of the function (Abdullah, 2009), catering packages by the hotel, hall or caterers (Abdullah, 2005) and various attractive wedding packages, have been commercialised and are highly priced.

In order to manage wedding expenses, each couple would surely need to prepare their sources of expenditure. It is crucial that early preparations are made to determine sources of expenditure by the individual involved in managing the wedding expenses, which would help the smooth management of wedding expenses. Individuals involved in the management of wedding expenses should have identified the sources to ensure that current and future finances are adequate and according to the estimated expenditure. A lack of initiative concerning this matter could lead to expenditures beyond the capability of the individual. According to al-Qaradawi (1993), a balance between income and expenditure is important in the management of the individual's expenditure. An imbalance between expenditure and income could lead to a culture of indebtedness. Currently, indebtedness is not something unusual for those who intend to get married. According to Datuk Nooh Gadut, the Advisor to the Johor Islamic Religious Council, it is common among the society these days to make loans from banking institutions to finance wedding receptions (Utusan Online, 2009). The indebtedness attitude is related to the preparation to identify sources for wedding expenses.

Therefore, this study intended to explore the sources of wedding expenses used by the MalayMuslim community. The study only focused on newly-married couples from the aspect of preparing sources of expenditure for managing wedding expenses. The sources of expenditure had differed from one participant to another. The findings were then analysed from an Islamic perspective to determine whether the source was endorsed by syarak or otherwise.

\section{METHODOLOGY}

This was a qualitative study that employed an exploratory approach. This study aimed to evaluate and explore a problem in detail as well as augment the existing corpus of knowledge and information about a phenomenon (Harun \& Abdullah, 2004) or a new unexplored issue (Neuman, 2012). This approach allowed the researcher to explore and evaluate a new issue about the behaviour of the Malay-Muslim community when dealing with wedding expenses, especially the sources of expenditure from a syarak perspective.

Data were collected using the semi-structured face-to-face interview method. A set of semistructured questions were developed and later validated by an expert in order to carry out the interview with participants of the study. The interview was held from May to September 2015 and the duration of each interview session lasted from 40 minutes to an hour. The recording was transcribed and analysed according to the thematic method as stipulated by the study. This method allows data to be examined, encoded and categorised based on the characteristics of the data in 
INTERNATIONAL JOURNAL OF ACADEMIC RESEARCH IN BUSINESS AND SOCIAL SCIENCES Vol. 8, No. 10, Oct. 2018, E-ISSN: 2222-6990 @ 2018 HRMARS

order to adduce themes related to the phenomenon being studied (Bowen, 2009). Thus, with the assistance of the ATLAS.ti Version 7.5.6 software, the analysis had specifically involved five steps, namely transcription, organising data, encoding, categorizing and conclusion. In the transcription process, the full interview script was produced. The data were organised, then encoded. Data encoding is very important in the qualitative analysis because it helps the researcher to retrieve the required data (Babbie, 2005) according to the needs of the study. Next, the encoded data were categorised based on a more generalised theme in order to arrive at a conclusion.

30 couples were selected as participants in the study based on the purposive / purposeful sampling method. The number of samples was still within a suitable range because in a qualitative study the sample should not be too big as it would be difficult to produce compact data as well as not too small as it would be difficult to achieve a level of saturation (Anthony \& Nancy, 2007). The participants in the study comprised couples, where either one of them originated from the states of Selangor, Johor, Kelantan or Kedah and who have been married for not more than 1 year from the date the data were collected. The selection was restricted to couples who married according to Malay marriage customs. In addition, the participants were selected from the four states because these four states had the highest frequency of marriages in 2012 according to zones, namely the north, south, central and east zones (Department of Statistics Malaysia, 2012). The high frequency of marriages in a state would produce a variety of wedding expenditure behaviour. The criteria of being married for not more than one year was stipulated to ensure the participants still had information about their wedding expenditure. The criteria of participants adhering to Malay marriage customs was relevant because those who celebrated their wedding without these customs would portray an expenditure behaviour that does not represent the usual or normal marriage expenditure of the Malay community.

Schedule 1 shows the participants' demographics. It is arranged according to the participants' state of origin, the highest level of education and the type of employment. Whereas, for the gross household income, the income of both husband and wife were added together.

Schedule 1: Participants' Demographics

\begin{tabular}{|c|c|c|c|c|c|}
\hline \multirow{2}{*}{\multicolumn{2}{|c|}{ State of Origin }} & \multicolumn{2}{|c|}{ Husband } & \multicolumn{2}{|c|}{ Wife } \\
\hline & & \multirow{2}{*}{$\begin{array}{l}\text { Frequency } \\
7 \text { persons }\end{array}$} & \multirow{2}{*}{$\begin{array}{c}\text { Percentage } \\
23.3 \%\end{array}$} & \multirow{2}{*}{$\frac{\text { Frequency }}{2 \text { persons }}$} & \multirow{2}{*}{\begin{tabular}{|c|} 
Percentage \\
$6.7 \%$
\end{tabular}} \\
\hline \multirow{3}{*}{ North Zone } & Kedah & & & & \\
\hline & Perak & 3 persons & $10.0 \%$ & 1 person & $3.3 \%$ \\
\hline & Pulau Pinang & None & $0 \%$ & 2 persons & $6.7 \%$ \\
\hline \multirow{2}{*}{$\begin{array}{l}\text { Central } \\
\text { Zone }\end{array}$} & Selangor & 5 persons & $16.7 \%$ & 7 persons & $23.3 \%$ \\
\hline & Negeri Sembilan & 2 persons & $6.7 \%$ & None & $0 \%$ \\
\hline \multirow{2}{*}{ South Zone } & Johor & 5 persons & $16.7 \%$ & 7 persons & $23.3 \%$ \\
\hline & Melaka & None & $0 \%$ & 2 persons & $6.7 \%$ \\
\hline \multirow{3}{*}{ East Zone } & Kelantan & 6 persons & $20.0 \%$ & 7 persons & $23.3 \%$ \\
\hline & Pahang & None & $0 \%$ & 1 person & $3.3 \%$ \\
\hline & Terengganu & 1 person & $3.3 \%$ & 1 person & $3.3 \%$ \\
\hline
\end{tabular}


INTERNATIONAL JOURNAL OF ACADEMIC RESEARCH IN BUSINESS AND SOCIAL SCIENCES Vol. 8, No. 10, Oct. 2018, E-ISSN: 2222-6990 @ 2018 HRMARS

\begin{tabular}{|c|c|c|c|c|}
\hline Sabah & 1 person & $3.3 \%$ & None & $0 \%$ \\
\hline Total & 30 persons & $100 \%$ & 30 persons & $100 \%$ \\
\hline \multirow{2}{*}{ Age } & \multicolumn{2}{|c|}{ Husband } & \multicolumn{2}{|c|}{$\begin{array}{c}\text { Wife } \\
\end{array}$} \\
\hline & Frequency & Percentage & Frequency & Percentage \\
\hline $18-21$ & None & $0 \%$ & 2 persons & $6.7 \%$ \\
\hline $22-25$ & 5 persons & $16.7 \%$ & 7 persons & $23.3 \%$ \\
\hline $26-29$ & 21 persons & $70.0 \%$ & 18 persons & $60.0 \%$ \\
\hline $30-33$ & 4 persons & $13.3 \%$ & 3 persons & $10.0 \%$ \\
\hline Total & 30 persons & $100 \%$ & 30 persons & $100 \%$ \\
\hline \multirow{2}{*}{ Level of Education } & \multicolumn{2}{|c|}{ Husband } & \multicolumn{2}{|c|}{ Wife } \\
\hline & Frequency & Percentage & Frequency & Percentage \\
\hline Malaysian Certificate of Education & 4 persons & $13.3 \%$ & 2 persons & $6.7 \%$ \\
\hline Certificate & 5 persons & $16.7 \%$ & 2 persons & $6.7 \%$ \\
\hline Diploma & 6 persons & $20.0 \%$ & 9 persons & $30.0 \%$ \\
\hline Bachelor's Degree & 13 persons & $43.3 \%$ & 15 persons & $50.0 \%$ \\
\hline Master's Degree & 2 persons $\mathrm{g}$ & $6.7 \%$ & 2 persons & $6.7 \%$ \\
\hline Total & 30 persons & $100 \%$ & 30 persons & $100 \%$ \\
\hline \multirow{2}{*}{ Employment } & \multicolumn{2}{|c|}{ Husband } & \multicolumn{2}{|c|}{ Wife } \\
\hline & Frequency & Percentage & Frequency & Percentage \\
\hline Professional & 15 persons & $50.0 \%$ & 13 persons & $43.4 \%$ \\
\hline Non-Professional & 11 persons & $36.7 \%$ & 7 persons & $23.3 \%$ \\
\hline Self-Employed / Business & 4 persons & $13.3 \%$ & 3 persons & $10.0 \%$ \\
\hline Unemployed & None & $0 \%$ & 7 persons & $23.3 \%$ \\
\hline TOTAL & 30 persons & $100 \%$ & 30 persons & $100 \%$ \\
\hline Gross Household Income & \multicolumn{2}{|c|}{ Frequency } & \multicolumn{2}{|c|}{ Percentage } \\
\hline RM 1,000 - RM 2,999 & \multicolumn{2}{|c|}{6 couples } & \multicolumn{2}{|c|}{$20.0 \%$} \\
\hline RM 3,000 - RM 4,999 & \multicolumn{2}{|c|}{13 couples } & \multicolumn{2}{|c|}{$43.3 \%$} \\
\hline RM 5,000 - RM 6,999 & \multicolumn{2}{|c|}{9 couples } & \multicolumn{2}{|c|}{$30.0 \%$} \\
\hline RM 7,000 - RM 8,999 & \multicolumn{2}{|c|}{2 couples } & \multicolumn{2}{|c|}{$6.7 \%$} \\
\hline TOTAL & \multicolumn{2}{|c|}{30 couples } & \multicolumn{2}{|c|}{$100 \%$} \\
\hline
\end{tabular}

Source: Interviews and Interview Confirmation Forms

According to the schedule above, participants had originated from 11 states, including one from East Malaysia. Although participants were restricted to only 4 states; however, data showed that almost every state was represented by the participants. This occurred because even though the participants were selected from the stipulated states; however, their spouses had originated from other states. From the aspect of age, the majority of participants were more than 20 years old. This indicates that the participants usually got married after reaching the age of 20 because when the interview was held they were all married for not more than a year. The age distribution, as shown in the graph, was uneven when the range for the highest frequency (26 to 29 years) was much bigger 
than the frequency for the other age groups. Data showed that participants' who married between the ages of 26 to 29 years comprised more than $50 \%$ from the total number of participants according to gender. Data distribution according to the highest level of education indicated that the majority of participants had finished their Bachelor's Degree. From the career aspect, it was found that all husbands had started work during their early marriage years, contrary to wives, where almost $1 / 3$ were umemployed. Participants' different working backgrounds had indicated a variety of gross household monthly incomes for each participant.

\section{FINDINGS}

The study found that there were four types of sources of expenditure that was used by the participants of the study, such as savings, contributions, loans and special funds. Following are the findings from the interview session with participants of the study. Data from the husband was represented by the symbol " $H$ ", while the wife was represented by the symbol "W", followed by numbers beginning from 01 to 30 .

\section{Saving}

Savings here refer to money that was saved by participants before they got married. Most participants, especially husbands, had used their savings as the main source of wedding expenditure. They made use of savings that they had accumulated while working, such as that related by $\mathrm{H} 10$ :

"I have been saving for a long time now. But I did not save money solely for the purpose of a wedding. Because when I was saving, I never thought of marriage. I did even have a plan, for example, 'I must have RM 10,000 for my wedding'. Some people, although they know each other, but have been engaged for two to three years, just to save money. Like me, my savings that I have, never thought of using it for wedding matters. I save because of the future. But when the time comes to get married, well the money that I have could be used."

(Source: Interview held on 7 June 2015 in Johor Bharu)

According to $\mathrm{H} \mathrm{10}$, although he did not plan to set up a savings fund specifically for wedding purposes; however, the savings from his work were used to manage his wedding expenses. The attitude of saving since starting work has had a positive impact because the savings had helped his personal wish come through.

As for participants who did not have any savings before deciding to get married, they only started to save after deciding to get married. $\mathrm{H} 04$ took more than a year and worked hard to accumulate his source of wedding expenditure. He and his wife explained:

"In the early month of January 2014, I told my wife, next year we will get married. That time we had just started saving. In more than a year we had saved some money. Like me, when I get some money, I would give it to my wife for safe keeping for our wedding. We actually had separate savings for wedding matters. For example, if this month, let's say I got RM 4,000, I would give my wife RM 2,500 for 
INTERNATIONAL JOURNAL OF ACADEMIC RESEARCH IN BUSINESS AND SOCIAL SCIENCES Vol. 8, No. 10, Oct. 2018, E-ISSN: 2222-6990 (C) 2018 HRMARS

safe-keeping. At that time, I also made side-incomes such as doing business at the convocation area and selling chicken rice during the fasting month."

(Source: Interview held on 19 May 2015 in Kuala Nerus)

H 23 stated that in order to accumulate enough savings during a short period of time, he had to save more than $1 / 3$ of his monthly income and said that:

"When I started work, my monthly salary was, for example, more than RM 2,500. I saved RM 1,000 and I spent RM 1,500 for myself as well as other needs."

(Source: Interview held on 29 August 2015 in Kota Bharu)

Next, there were some participants who were willing to use their allowances and education loans as part of their source of expenditure. $\mathrm{H} 15$ and $\mathrm{H} 18$ said:

"When I wanted to get married, I was on study leave (overseas) and drawing full pay. Per month, my full pay together with study leave allowances, I got approximately 1,000 pounds. From that money, I only used half per month, whereas the remainder I saved for my wedding."

(Source: Interview held on13 June 2015 in Alor Setar)

"The money that is used was from my own income. Besides that, I also used the money I got from National Higher Education Fund Corporation (NHEFC). NHEFC was a lot, as much as my income."

(Source: Interview held on 7 August 2015 in Pasir Puteh)

According to $\mathrm{H} \mathrm{15}$, who was a government-sponsored student and $\mathrm{H} 18$, who took a loan to continue his studies, they both had used their allowances and loans to make up their wedding expenses.

\section{Contribution}

Contributions from parents, family members and friends were a source of wedding expenses for some of the participants. Many parents had paid for several items in the wedding expenses list, especially the wedding banquet. Moreover, there were some parents who footed the whole bill, especially those who had daughters who were still studying or unemployed. W 01, who was still studying in an Institute of Public Higher Education (IPHE) explained:

"Mum and Dad footed my entire wedding expenses bill. It could be said that $90 \%$ of the expenses were borne by my parents using their own money."

(Source: Interview held on 10 May 2015 in Kuala Terengganu)

As for I 26, although she was already working, a big part of her wedding expenses was borne by her parents. She stated that: 
INTERNATIONAL JOURNAL OF ACADEMIC RESEARCH IN BUSINESS AND SOCIAL SCIENCES Vol. 8, No. 10, Oct. 2018, E-ISSN: 2222-6990 (C) 2018 HRMARS

"For this wedding, the whole family had joined in and sponsored it. I only spent a little, not much. Moreover, I did not have much savings. Just that I received a bonus at the beginning of the year and that is what was used."

(Source: Interview held on 4 September 2015 in Shah Alam)

There were male participants who received contributions from their parents. $\mathrm{H} 23$ elaborated about his "mas kahwin" (obligatory dowry) expenses:

"I had just started work for about four months before I got married. At that time, I managed to save around RM 3,000 to RM 4,000. Actually, that was not enough for the "mas kahwin" (obligatory dowry) of RM 10,000. The remainder was covered by my parents."

(Source: Interview held on 29 August 2015 in Kota Bharu)

According to $\mathrm{H} 23$, he could only afford about RM 4,000 to fulfil the "mas kahwin" (obligatory dowry) condition stipulated by the bride's side of RM 10,000. The remainder of the amount was contributed by his parents. As for $\mathrm{H} 05$ and $\mathrm{H} \mathrm{10,} \mathrm{their} \mathrm{parents} \mathrm{had} \mathrm{paid} \mathrm{for} \mathrm{the} \mathrm{cost} \mathrm{of} \mathrm{the} \mathrm{banquet}$ reception. They explained:

"As for my wedding banquet, my mother bore the cost of the wedding banquet. The banquet expenses were the most expensive item, which was almost RM 12,000 and my mother paid for it."

(Source: Interview held on 30 May 2015 in Shah Alam)

"The expenses covered by my parents were for the banquet. They spent RM 13,000 for the banquet."

(Source: Interview held on 7 June 2015 in Johor Bharu)

Besides parents, family members, neighbours and friends of the participants had also contributed. The contributions were not extravagant but rather a form of support and cooperation aimed at assisting the couple. W 19 stated that all her husband's siblings had contributed an item in the engagement gift set. She said:

"My husband was the youngest child. He has eight siblings. So, during the engagement, each sibling had bought a gift as part of the engagement gift set."

(Source: Interview held on 14 August 2015 in Shah Alam)

$\mathrm{H} 04$ also stated that the local community had given various contributions:

"During the wedding banquet, my uncles gave several kilograms of sugar. Some gave about ten bags of rice. Besides my relatives, the village folk gave sugar etc."

(Source: Interview held on 19 May 2015 in Kuala Nerus) 
INTERNATIONAL JOURNAL OF ACADEMIC RESEARCH IN BUSINESS AND SOCIAL SCIENCES Vol. 8, No. 10, Oct. 2018, E-ISSN: 2222-6990 (C) 2018 HRMARS

There were some family members and good friends who had contributed towards expenses incurred for several items such as payment for the makeup and entertainment. This was stated by W 12 and W 18:

"My place provides entertainment during wedding functions. The cost of the entertainment was sponsored by my aunty for approximately RM 700. She offered to pay the full amount."

(Source: Interview held on 8 June 2015 in Kota Tinggi)

"My friend sponsored the cost of the makeup for the wedding. My friend took me for the makeup session and paid for it."

(Source: Interview held on 7 August 2015 in Pasir Puteh)

Another form of contribution by family members was sponsoring side dishes to the main menu during the banquet. I 27 stated that:

"Some relatives gave support by providing side dishes. They gave according to a household or family. For example, one family wanted to give laksa, so they prepared laksa. Some gave kuih-muih."

(Source: Interview held on 5 September 2015 in Kuala Lumpur)

What was explained by 127 is one of the present trends, which is to create a variety of side dishes besides the main menu. These side dishes were prepared by neighbours and family members.

\section{Loan}

Loans mentioned here refer to money given to an individual for a temporary period and needed to be repaid later (Kamus Dewan, 2010). A loan is a source of expenditure in the form of money borrowed by the participant from any party or in other words, a form of debt. The study found that 11 participants (mostly husbands) had presumed the loan to be one of the sources of expenditure. The loan was from family members, banking institutions or loan facilities and pawn shops. The loan was the second source of expenditure after savings, though there were some who treated it as the main source.

W 08 had borrowed some money from family members to manage her wedding expenses. For her, borrowing from family members was better than taking a bank loan. She stated that:

"This source of expenditure, some were my own money, some were a loan from my dad, which I could pay back later after my marriage. I did not want to take a bank loan. If I did, I would feel the burden because of the interest from the loan."

(Source: Interview held on 5 June 2015 in Segamat) 
INTERNATIONAL JOURNAL OF ACADEMIC RESEARCH IN BUSINESS AND SOCIAL SCIENCES Vol. 8, No. 10, Oct. 2018, E-ISSN: 2222-6990 @ 2018 HRMARS

According to $\mathrm{W} 08$, the loan from her father was not a burden because she did not have to pay any interest. I 30 explained that her mother-in-law had offered a loan to her husband:

"For the expenditure by my husband, his mother gave him a loan. Even now he is still re-paying the loan. His brother did the same when he got married. His mother said that if she did not give the loan, they could not be able to get married. The money would never be enough."

(Source: Interview held on 20 September 2015 in Petaling Jaya)

The explanation by I 30 shows that the giving of a deposit as a loan by parents has become a normal practice in her husband's family. This method was aimed at assisting the wishes of the children who intend to marry.

Next, for participants who were involved with bank loans, there were some who made housing loans and used a part of the loan as a source of expenditure. $\mathrm{H} 21$ explained her strategy:

"I did not use my savings for my wedding, but I used the extra money from my housing loan. I bought a single storey house. According to the market value the house costs RM 130,000. Hence, I negotiated with the owner for RM 95,000. I marked-up the loan to almost 90\%. From RM 130,000, I got RM 120,000. I paid the owner RM 95,000, plus the lawyer's fees it came up to RM 100,000. The remainder, I had in hand RM 20,000. So, the money I used for the wedding reception. The housing loan was RM 120,000, if according to the commitment with the bank, I have to pay RM 625 a month. So, I rented the house I bought for RM 700 a month. So, the monthly loan payment is settled."

(Source: Interview held on 15 August 2015 in Bandar Enstek)

The explanation above by $\mathrm{H} 21$ shows that a loan was made into the main source of expenditure. However, she did not feel the pressure of the burden of paying back the loan because the loan was not solely for the wedding. Moreover, the house bought with the loan was rented out and the rent had helped re-pay the loan. That act was a good tactic consistent with her experience as an Assistant Accountant of more than two years and earning a stable monthly income. This situation entitled her to apply for a housing loan at an early marrying age.

Compared to $\mathrm{H} 21$, several other participants had made personal loans solely for bearing the wedding expenses. $\mathrm{H} 20$ stated that he made the loan of RM 30,000 for the purpose of the wedding:

"The money meant for wedding expenses of RM 30,000 was from a loan. Because during the "merisik" and engagement, I had used my savings. When I wanted to get married, I thought that there must surely be huge expenses involved. That is why I thought I had to make a loan because there was no time to save money."

(Source: Interview held on 15 August 2015 in Gombak) 
What was stated by $\mathrm{H} 20$ indicates that he had foreseen the need to make a loan from the beginning stages of the wedding plan. This is different from the perception of several participants who stated that a loan was not the main choice; rather, the last option available. Among them was H 24, who stated that:

"I thought the loan was the last choice. Before making the decision to make a loan, I had tried to draw up a budget but the money I had was not enough. That's why I made the loan. As if the bank loan was the last option for me to solve my financial matters."

(Source: Interview held on 29 August 2015 in Kota Bharu)

He then admitted that a loan from the bank was not the best way to solve the wedding expenses issue and stated that:

"For me, it is not good actually to make a bank loan. Because we have to service the loan on a monthly basis. But when am I to settle my wedding matters, we do not have a choice, I was forced to borrow. It is rare now to see people getting married without making a loan. But with my friends, out of ten who want to get married, nine were surely to make a loan."

(Source: Interview held on 29 August 2015 in Kota Bharu)

According to the statement by the participant above, the loan from the banks was one way of securing a source for wedding expenses. Although some knew of the implications of a loan, they did not have any alternative to overcome their financial problem.

Other than bank loans, one participant chose to pawn his property in order to obtain a source for his expenditure. According to $\mathrm{H} 02$ :

"I am the type who keeps property in the form of gold. I use the Ar-rahnu scheme to obtain money to prepare for my wedding function. Although Ar-rahnu is still in the form of a loan, but it is under our control. I do not feel the borrowed is used up just like that. If it is a personal loan, it is like there are no returns. So, the burden of responsibility multiplies."

(Source: Interview held on 13 May 2015 in Kuala Terengganu)

$\mathrm{H} 02$ was of the view that pawning the property was better than taking a loan, as done by most of the other participants. Nevertheless, the reality is that the participant still has to pay back to repossess the property he pawned.

\section{Special Fund}

Special funds are in the form of a planned contribution by the local community as a group to partly fund wedding expenses and it is a source of wedding expenses. However, this source is not the main 
INTERNATIONAL JOURNAL OF ACADEMIC RESEARCH IN BUSINESS AND SOCIAL SCIENCES Vol. 8, No. 10, Oct. 2018, E-ISSN: 2222-6990 @ 2018 HRMARS

source for the participant. This study found that only three participants in this study received support from this source of expenditure. For $\mathrm{H} 21$, he had used all the contributions from the village fund, or also known as "duit pakat" to cover the costs of the wedding banquet. He explained:

"Like in Kedah, we have the 'duit pakat' concept. 'Duit pakat' is like the "kutu" system. When someone has a wedding banquet, all the village folk would come together and contribute money. They would join the 'duit pakat' group and collect contributions for those getting married. So, for my wedding the cost for the beef and cooking was about RM 7,000 and I used the 'duit pakat'. This 'Duit pakat' does not involve monthly re-payments, it follows who is next in turn to have a wedding banquet. For example, when there is a wedding banquet, they will collect contributions of RM200 from one household."

(Source: Interview held on 15 August 2015 in Bandar Enstek)

The custom practiced in the village where $\mathrm{H} 21$ comes from is a noble custom because it emphasises the concept of cooperation amongst the village folk. They collect funds each time there is a wedding function. Besides $\mathrm{H} 21$, this method was also used during the wedding function of $\mathrm{H} 04$ and $W 30$. Hence, this fund was not used for the banquet but to supplement the whole function, such as door-gifts for guests etc. H 04 and W 30 stated:

"For the cost of the canopy, I used the proceeds from my village's 'duit pakat'. As for the canopy, it did not involve the budget because no money was involved. Once a year we pay to the 'duit pakat', which is from RM 10 to RM 20 only. If in a family there are ten children, all of them can use the canopy when they get married. The village folk have an organization under the Head village man."

(Source: Interview held on 19 May 2015 in Kuala Nerus)

"The money for preparing the "bunga telur", we collected from every house. There are many households in the flat, we collected RM 20 from each house for preparing the "bunga telur". Every time there is a function this is the practice in our flat area. Then when it is the turn of another youth to get married, we would do this again, we will collect money from each house."

(Source: Interview held on 20 September 2015 in Petaling Jaya)

According to the comments above, it is clear that the source of expenditure for $\mathrm{H} 04$ and $\mathrm{W}$ 30 that made their wedding a success was the special fund initiated by the local community. The difference between the two participants was that $\mathrm{H} 04$ held his wedding in a village in Kedah, while W 30 held her wedding in the middle of the city in Kuala Lumpur.

\section{DISCUSSION}

The findings of this study show that the participants of the study had four sources of expenditure, namely savings, contributions, loans and special funds. The use of savings as the main source of 
expenditure is one of the efforts that indicate the earnestness of the participant, especially the husband, in bearing the wedding expenses. All the male participants had made savings as the main source of expenditure, compared to female participants because there were still some who depended entirely on their parents. Expenditure based on savings not only shows the earnestness of the husband in managing wedding expenses but it also reflects the husband's responsible attitude in this matter. His action is consistent with the demands of Islam pertaining to the management of wedding expenses. According to Husin (2017), there are two main elements of expenditure in Islamic wedding procedures, namely obligatory dowry (mas kahwin), as an obligatory expense and walimatul urus, as an element of preferred expense.

Both these elements are specifically demanded upon the husband. Based on the al-Qur'an and Hadith, the Ulama Fiqh (Ibn Qudamah, 1986; Al-Mawardi, 1999) have unanimously stated that the individual who is responsible for paying the obligatory dowry (mas kahwin) is the husband. However, views by some Iraqi academicians were clearly contradictory to the al-Quran by stating that a husband who is a slave is not obligated to pay the obligatory dowry (mas kahwin) for a wife who is also a slave (Al-Qurtubi, 2002). Organising the walimatul urus is also the responsibility of the husband (Al-Qalyubi \& Al-Umayrah, 1956; Al-Jaziri, 1999), as seen in the command by Rasulullah SAW to 'Abd al-Rahman ibn 'Auf to implement the walimatul urus (Al-Nawawi, d.u). According to al-Haytami (d.u), the wedding banquet borne or implemented by someone other than the husband without his permission is not consistent with the meaning of walimatus urus and indirectly the function would not receive the blessings as a walimatul urus. The stipulation that the husband is the individual who is responsible for fulfilling the two main demands shows the responsibility borne by them in starting their lives as the head of the household. Therefore, it is a wise decision for participants with a husband's status to use their savings when managing wedding expenses.

From the aspect of starting a savings, the findings showed that participants who did not have any savings before marriage had difficulties in identifying a source of expenditure compared to those who were in the habit of saving. They had worked hard to save a sum of money before the wedding function and some had even saved almost half their monthly salaries for over a period for their wedding expenses. Their difficulty in providing a source of expenditure was not felt by some participants who initially had some savings before deciding to get married. This supports the view of Dawabah (2010), who stated that Islam encourages the habit of saving to ensure a better future for the individual, especially in times of need. Through the habit of saving, it would be easier for Muslims to deal with emergencies and unforeseen circumstances that need financial assistance.

The benefits of saving were specifically mentioned by Rasulullah SAW. The Prophet SAW had told a companion to keep a portion of his property for future use. Rasulullah SAW exhorted:

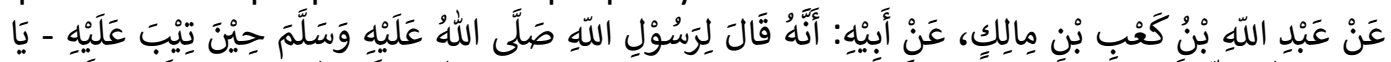

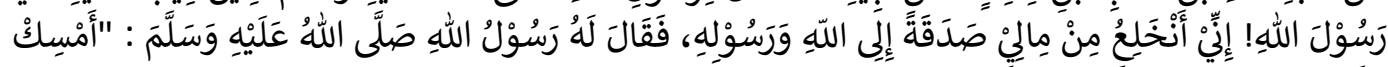

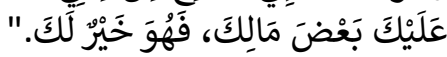

Abdullah bin Ka'b bin Malik narrated from his father, that he said to the Messenger of Allah, when his repentance was accepted: "O Messenger of Allah! I want to give 
INTERNATIONAL JOURNAL OF ACADEMIC RESEARCH IN BUSINESS AND SOCIAL SCIENCES Vol. 8, No. 10, Oct. 2018, E-ISSN: 2222-6990 @ 2018 HRMARS

all my wealth in charity for Allah and His Messenger." The Messenger of Allah said to him: "Keep some of your wealth for yourself; that is better for you."

(Hadith Narrated by al-Nasa'i, Kitab al-Ayman wa alNudhur, Bab Idza Nadhar thumm Aslam Qabl an Yafi, no. Hadis 3854)

Based on the hadith above, among the benefits of saving was the benefit accrued by the individual himself. In a wider context, al-Qaradawi (1995) stated that the practice of saving could produce a Muslim community capable of benefitting from the savings for the betterment and interest of each one. Using the extra money from the sponsorship or study loan as a source of expenditure is a positive move towards managing personal finances. Efforts to be thrifty in using the money could enable them to save the extra money and not to use it on non-beneficial items. This leads to the saving eventually helping them to prepare a source for their wedding expenditure. The situation faced by these participants indicates the existence of a sense of financial literacy. Without this realisation they would not be able to save the extra money or use the extra money for nonbeneficial matters.

According to Rahman \& Ibrahim (2016), financial literacy has a positive and significant relationship with an attitude to save, especially among university students. In addition, the findings also showed the enthusiasm of the participants to marry at a young age. Although they were still students, they did not cite the busy schedule to seek knowledge as an excuse for not planning and thinking about matters related to marriage after having the desire to do so. In Islam, marriage is encouraged for individuals who have the desire and capability to pay the obligatory dowry (mas kahwin) and wife support (nafkah isteri), regardless of whether they are religious or students (AlBujayrimi, 1996). Moreover, based on the call to marriage by Rasulullah SAW, the youth, such as the participants in this study, were strongly encouraged to get married (Al-Asqalani, 2001).

The action of parents to bear the wedding expenses is one form of support that shows their feeling of responsibility towards their children. It is a decorum that parents bear the wedding expenses of their children, either wholly or limited to certain items, such as the wedding banquet, as mentioned by some of the participants. As for contributions towards the banquet, although the individual responsible for initiating the walimatul urus is the husband (Al-Qalyubi \& Al-'Umayrah, 1956), hence, this does not mean that parents are not allowed to bear the cost for the son. Hence, from the aspect of religious law (hukum), the banquet borne by the parents would receive sunat (non-obligatory or permitted) rewards related to walimatul urus when performed with the permission of the husband (Al-Haytami, d.u). As for contributions by family members other than parents and good friends, it actually supports the views of Kasimin (2002), who stated that among the traditional practices of the Malay community when celebrating a wedding is to provide assistance during the wedding, such as providing fresh rations like sugar, rice etc. according to the capability of each person. The contributions are a form of cooperation that is greatly encouraged by Islam. According to Yusuf (d.u), family members, neighbours and friends would be blessed if they help individuals who intend to get married in order to alleviate the burden posed by wedding expenses 
INTERNATIONAL JOURNAL OF ACADEMIC RESEARCH IN BUSINESS AND SOCIAL SCIENCES Vol. 8, No. 10, Oct. 2018, E-ISSN: 2222-6990 @ 2018 HRMARS

borne by them. In a wider context, Al-'Uzayzi (2003) stated that helping one another in the management of property is much encouraged and is an Islamic economic principle intended to safeguard the mutual benefits enjoyed amongst Muslims and humanity by fulfilling various aspects of goodness.

Managing wedding expenses using a loan indicates that there were some participants who were not capable of covering the while wedding cost. The financial situation before marriage and the need to prepare an allocation within a short period of time had forced the participant to go into debt. This situation is encouraged with the existence of the banking industry that frequently entices the community to go into debt. According to Ismail and Lukman (2013), competitive marketing activities by parties who want to expand their products has become a factor in increasing the level indebtedness in the community today. The various loan schemes had also influenced the community, especially those who are in a desperate financial situation, to make a loan as the last resort, as mentioned by some of the participants. In addition, the findings also showed that some participants had formed a perception about the need to go into debt in order to cover wedding expenses. Some of them supported the view of the family, whereby without going into debt, the intention to get married would be difficult to fulfil. There were some who witnessed the experience of innumerable local youths involved in debts to pay wedding expenses as a common practice before marriage. A perception such as this indicates that they had earlier perceived the need to go into debt in order to get married. This perception reflects the attitude that could influence the desire to go into debt. Azman, Zakaria and Marican (2017) found that the attitude of the household regarding debts is among the factors that causes the household to go into debt. Those who go into debt are those with a pro-debt attitude from a behavioural aspect. From the aspect of age of those involved in loans, the findings showed views by several parties who had endorsed the trend of indebtedness among youth in order to bear the cost of weddings (Utusan Online, 2009). What was emphasised by the Association of Education and Research for Malaysian Consumers as well as the Centre for Research and Consumer Resources related to the involvement of $47 \%$ of young employees with the culture of debt (Central Bank of Malaysia, 2013) was seen to support the findings of this study. This was because all the participants in this study were aged 33 years and below.

According to Al-Qaradawi (1993), debt is something that is allowed (diharuskan) in Islam. Rasulullah SAW himself had carried out commercial activities by going into debt. Aziz, Adnan and Ismail (2017) stated that although Rasulullah SAW had gone into debt, His attitude towards indebtedness only involved matters of need in order to fulfil maslahah daruriyyah, and not solely for psychological reasons, such as indulging in luxuries etc. Among the situations that caused Rasulullah SAW to go into debt was jihad and defence, to buy food and to avoid blasphemy by those who have just embraced Islam (muallaf). Examples of these situations clearly shows that debt in this manner is a pressing need because it involves expenditure to safeguard lives and religion. Expenditure such as this is included in the expenses for daruriyyah needs. According to al-Shatibi (1997), daruriyyah needs are something that is absolutely needed in the lives of humans for the good of religion as well as life on earth. Hence, if these needs are not fulfilled, human life would be under duress in this world and in the afterlife. Kadir, Kamri and Kassim (2013) stated that a situation that enables a Muslim to go 
into debt is when a Muslim is in a desperate situation and there is no way to remedy the situation except by borrowing. This view was supported by Mohamad et al., (2014), who stated that indebtedness is permissible in an unavoidable situation.

Although the participants in this study could not provide an actual account of items bought with the loan; however, investigations have shown that those involved in debts had spent on elements that were not a need or otherwise called daruriyyah needs. The expenditure included items such as rental of the bridal pedestal, entertainment, photography, cosmetic makeup etc., which was more towards a big function that adhered to customs and current trends. Expenditure such as this is not intended to fulfil pressing needs or daruriyyah, rather it is included in expenditure towards tahsiniyyah needs. Ibn Ashur (2001) explained that tahsiniyyah needs refer to something supplementary that makes human life more pleasant. According to Rahman (1975), this kind of need adds comfort and convenience to human life. Expenditure to fulfil tahsiniyyah needs by going into debt is a form of expenditure inconsistent with the Islamic consumerism concept. Mohamad et al., (2014) stressed that loans made solely to fulfil the comforts of life is inappropriate because it contradicts Islamic values. Moreover, according to Idris and Yusop (2009), expenditure to fulfil tahsiniyyat needs is only permitted if it does not involve hire-purchase.

According to the discussions above, it was found that expenditure sourced from loans or debt from any party to be used as wedding expenses is a practice that is not encouraged, especially when the elements in the expenditure are only meant to fulfil tahsiniyyah needs. According to Shahir (2012), loans intended for a big scale wedding reception is categorised as a debt that is not needed by a Muslim. A wedding reception should be carried out according to the budget of the individual who is involved and not a budget that exceeds his financial capabilities. Debt should not be the main solution to matters related to wedding expenses; rather it should be avoided at all costs in order to safeguard the wellbeing of the couple from the burden of debt in such an early age in life. What is more important is to settle these matters within the means available without needing to fulfil the demands of customary rites and current trends that involve tahsiniyyat needs, which are harus (permitted) if fulfilled.

As for the source of expenditure based on special funds, the practice of setting up a fund among the community as adduced by the three participants is a form of planned group cooperation. This method is an alternative for the local community to lessen the wedding expenses of each participant who wants to get married and is also a practice consistent with the syarak. Al-Nawawi (d.u) stated that Islam encourages assistance for those who wish to uphold walimatul urus. Cooperation towards such a good deed as this is a sunat demand (Al-Basyuni, 1988). According to Husin (2016), the marriage sirah of Rasulullah SAW portrayed several episodes that showed the existence of the helping one another and cooperation concept by His companions during the His walimatul urus. The cooperation concept is consistent with the exhortation by Allah SWT:

"And cooperate in righteousness and piety, but do not cooperate in sin and aggression..."

Al-Ma'idah 5: 2 
According to the verse above, the cooperation extended in the special fund concept was a form of assistance towards goodness. The assistance extended not only propagates the attitude of providing assistance amongst Muslims, but it also instils the feeling of esprit de corps in the community.

\section{CONCLUSION}

A source for wedding expenses must be prepared by every Muslim who plans to get married. The findings showed that there were four forms of sources of wedding expenses that were used by the participants. Out of the four sources, expenditure based on savings, contributions and special funds are the sources of expenditure endorsed by Islam. Whereas, wedding expenses obtained through loans from any party is not an ideal source from a syarak's perspective. Moreover, the response by the participants to go into debt solely to manage their wedding expenses is not wise. Although Islam has never forbidden anyone from going into indebtedness, its need in matters pertaining to wedding expenses is still presumed to be not an urgent need.

\section{Acknowledgement}

This article is part of a research fund sponsored and managed by the Center for Research and Innovation (RMIC), Sultan Zainal Abidin University (UniSZA), Gong Badak Campus 21300 Kuala Nerus, Terengganu, Malaysia.

\section{References}

Abdullah, F. (2009). Dari halaman rumah ke dewan merak kayangan. SARI Jurnal Alam dan Tamadun Melayu. 27(1), 97-107.

Abdullah, S. (2005). Adat perkahwinan Melayu. Selangor: Pustaka Cahaya Intelek.

Al-'Asqalani, A. I. A. I. H. (2001). Fath al-bari. (ed). Ibn Baz, A. A. \& Abd al-Baqi, M. F. Vol. 9. Qaherah: Maktabat al-Misr.

Al-'Uzayzi, M. R. A. A. (2003). Mabadi' al-nizam al-iqtisad fi al-islam wa mumayyizatuh. 'Amman: Dar Juhaynah.

Al-Basyuni, S.a'id A. A. M. (1988). Al-hurriyyah al-iqtisadiyyah fi al-islam wa atharuha fi al-tanmiyyah. Qaherah: Dar al-Wafa'.

Al-Bujayrimi, S.ulayman I. M. I. U. (1996). Al-bujayrimi 'ala al-khatib. Vol. 4. Beirut: Dar al-Kutub 'Ilmiyyah.

Al-Haytami, S. A. A. I. H. (d.u). Tuhfat al-muhtaj bi sharh al-minhaj. Vol. 7. Qaherah: Matba'ah Mustafa Muhammad.

Al-Jaziri, A. A. (1999). Kitab al-fiqh 'ala madhahib al-arba'ah. (ed). Ismail, M. B. Vol. 4. Qaherah: Dar al-Manar.

Al-Mawardi, A. A. A. I. M. 1999. Al-hawi al-kabir fi fiqh madhhab al-imam al-shafi'i. (ed). Muawwad, A. M. \& Abd al-Mabud, A. A. Vol. 9. Beirut: Dar al-Kutub al-Ilmiyyah.

Al-Nasa'i, A. A. A. I. S. (2000). Sunan al-nasa'i, in al-Shaykh S. I. A. A. (ed). Mawsu'at al-hadith al-sharif: al-kutub al-sittah. Riyadh: Dar al-Salam.

Al-Nawawi, A. Z. M. A. (d.u). Sahih muslim bi sharh al-nawawi. Vol. 9. Qaherah: Dar al-Taqwa. 
INTERNATIONAL JOURNAL OF ACADEMIC RESEARCH IN BUSINESS AND SOCIAL SCIENCES

Vol. 8, No. 10, Oct. 2018, E-ISSN: 2222-6990 @ 2018 HRMARS

Al-Qalyubi, S. A. A. \& Al-'Umayrah, S. A. A. (1956). Hashiyatan. Vol. 3. Qaherah: Maktabah wa Matba'ah Mustafa al-Babi al-Halabi wa Awladih.

Al-Qaradawi, Y. (1993). Mulamih al-mujtama' al-muslim alladhi nanshuduh. Qaherah: Maktabah Wahbah.

Al-Qaradawi, Y. (1995). Dawr al-qiyam wa al-akhlaq fi al-iqtisad al-islami. Qaherah: Maktabah Wahbah.

Al-Qurtubi, A. A. M. (2002). Al-jami' li ahkam al-qur'an. (ed). Al-Hafnawi, M. I. \& Uthman, M. H. Vol. 4. Qaherah: Dar al-Hadith.

Al-Shatibi, A. I. I. (1997). Al-Muwafaqat. Ed. Abu 'Ubaydah Mashhur ibn Hasan. Vol. 2. Jeddah: Dar Ibn 'Affan.

Amran Kasimin. 1989. Istiadat perkahwinan Melayu: satu kajian perbandingan. Kuala Lumpur: Dewan Bahasa dan Pustaka.

Anthony, J. O. \& Nancy, L. L. (2007). Sampling designs in qualitative research: making the sampling process more public. The Qualitative Report. 12 (2), 238-254.

Azahari, R., Saripudin, K. N. \& Wahab, R. A. (2009). Hubungan di antara faktor demografi dengan penentuan kadar hantaran: kajian di Perlis, Kedah, Pulau-Pinang dan Perak. Jurnal Fiqh. 6, 107124.

Aziz, I. A., Adnan, A. A. \& Ismail, N. A. (2017). Fenomena keberhutangan di zaman Rasulullah. Ulwan's Journal. 1, 143-177.

Azman, N., Zakaria, R. H. \& Marican, S. (2017). Sikap isi rumah terhadap huang dan keberhutangan: kajian kes di lembah Klang, Malaysia. The Malaysian Journal of Social Administration. 9(1), 5986.

Babbie, E. (2005). The basics of social research. Ed. 3. United States of America: Thomson Wadsworth.

Bowen, G. A. (2009). Document analysis as a qualitative research method. Qualitative Research Journal. 9( 2), 27-40.

Central Bank of Malaysia. 2012. Kajian: pekerja muda hadapi masalah hutang serius. Ringgit. November 2012. Kuala Lumpur: Bank Negara Malaysia.

Dawabah, A. M. (2010). Al-lqtisad al-Islami: Madkhal wa Manhaj. Qaherah: Dar al-Salam.

Department of Statistics Malaysia. (2012). Retrieved March 13, 2013, from http://www.statistics.gov.my/portal/download Labour/files?BPTMS/PST-Siri6.pdf.

Harun, A. \& Abdullah, N. (2004). Metodologi penyelidikan ekonomi dan sains sosial. Singapura: Thomson.

Husin. S. N. M. S. (2016). Analisis konsep perbelanjaan perkahwinan Rasulullah SAW". Jurnal Usuluddin. 43, 109-136.

Husin. S. N. M. S. (2017). Gelagat perbelanjaan perkahwinan masyarakat Melayu muslim menurut perspektif syariah. PhD Thesis. Uniersiti Malaya.

Ibn'Ashur, M. A. (2001). Maqasid al-shari'ah al-islamiyyah. (ed). Al-Maysawi, M. A. Vol. 2. 'Amman: Dar al-Nafa'is.

IbnQudamah. (1986). Al-mughni. (ed). Al-Turki, A. I. A. A. \& Al-Halw, A. A. M. Vol. 10. Riyad: Dar 'Alam al-Kutub.

Idris, M. A. A. \& Yusop, N. Y. M. (2009). Pemakaian fiqh awlawiyyah dan prinsip maslahah dalam teori penggunaan islam. Jurnal Kolej Islam Pahang Ahmad Shah. 10, 137-157. 
INTERNATIONAL JOURNAL OF ACADEMIC RESEARCH IN BUSINESS AND SOCIAL SCIENCES

Vol. 8, No. 10, Oct. 2018, E-ISSN: 2222-6990 @ 2018 HRMARS

Ismail, M. N. \& Lukman, A. S. (2013). Perbankan Islam di Malaysia: membantu atau membahayakan ummah?, in Ali, A. K. \& Chik, M. N. (ed). Maqasid syariah, isu-isu kepenggunaan: realiti dan cabaran. Kuala Lumpur: Persatuan Ulama' Malaysia.

Kadir, A. H. A., Kamri, N. A. \& Kassim, B. (2013). Maqasid syariah: isu-isu kepenggunaan, realiti dan cabaran, in Ali, A. K. \& Chik, M. N. (ed). Maqasid syariah isu-isu kepenggunaan: realiti dan cabaran. Shah Alam: Persatuan Ulama Malaysia.

Kasimin, A. (2002). Perkahwinan melayu. Kuala Lumpur: Dewan Bahasa dan Pustaka.

Maarof, Y. \& Majid, M. K. A. (2015). Panduan fiqh munakahat. Kuala Lumpur: Dewan Bahasa dan Pustaka.

Mohamad, S., Rahman, N. N. A., Rahman, A. A., Razif, N. F. M. \& Saripudin, K. N. (2014). Debt among credit card users, in Rahman, A. A., Ahmad, W. M. W. \& Mohamad, S. (ed). Islamic economisc, banking and finance: concept and critical issues. Kuala Lumpur: Pearson.

Neuman, W. L. (2012). Basics of Social Research Qualitative and Quantitative Approaches. Ed. 3. Boston: Pearson.

Penang Consumer Association. (1987). Anda dan wang anda: bagaimana menyimpan \& berbelanja dengan bijak. Pulau-Pinang: Persatuan Pengguna Pulau Pinang.

Rahman, A. (1975). Economic doctrines of islam. Vol. 2. Lahore: Islamic Publications Ltd.

Rahman, A. A. \& Ibrahim, M. (2016). Faktor penentu sikap menabung bagi mahasiswa universiti. Jurnal Muamalat. 9, 72-88.

Rahman, Z. A. 2007. Mahar in Malaysia: The Law Revisited. Shariah Law Reports. 4, 1-19.

Salleh, K. 2010. Adat dan pantun perkahwinan melayu. Kuala Lumpur: Tinta Publishers.

Shahir, R. M. (2012). Bijak mengurus wang. Kuala Lumpur: Galeri IImu.

Strange H. (1981). Rural malay women in tradition and transition. New York: Praeger.

Utusan Online. (2009). Kes cerai di johor tertinggi. Retrieved March 10, 2013, from http://www.utusan.com.my/utusan/info.asp?y=2009\&dt=0331\&pub=Utusan Malaysia\&sec=J ohor\&pg=wj 01.htm.

Yusuf, H. M. (d.u). Adab al-'aqd wa al-zifaf fi al-islam. Qaherah: Dar al-I'tisam. 